\title{
Expression of MHC I and NK ligands on human CD133 + glioma cells: possible targets of immunotherapy
}

\author{
Anhua Wu $\cdot$ Steve Wiesner $\cdot$ Jing Xiao $\cdot$ \\ Katya Ericson - Wei Chen - Walter A. Hall · \\ Walter C. Low $\cdot$ John R. Ohlfest
}

Published online: 12 April 2007

(C) Springer Science+Business Media B.V. 2007

\section{Erratum to: J Neurooncol}

\section{DOI 10.1007/s11060-006-9265-3}

Unfortunately, an error occurred in the first paragraph of the results section of this article. The paragraph should read:

To obtain human CD133-positive cells, we cultured freshly isolated glioma samples in vitro in stem cell media as described in the methods; under these culture conditions we observed the formation of tumor spheres in all the cultures (tumor sphere formation is a hallmark of BTSCs [15-19]). Immunofluorescent staining revealed that the tumor spheres were comprised of CD133-positive cells (Fig. 1C). After plating in commitment media to cause adherence and differentiation, tumor spheres differentiated into adherent GFAPpositive (astrocyte marker) and Tuj1-positive (neuronal marker) cells (Fig. 1E, G), which is consistent with results of other studies $[15,28]$ and confirms the existence of multipotent CD133-positive cells in our samples.

The online version of the original article can be found at http:// dx.doi.org/10.1007/s11060-006-9265-3

A. Wu $\cdot$ S. Wiesner $\cdot$ J. Xiao $\cdot$ K. Ericson $\cdot$

W. A. Hall · W. C. Low · J. R. Ohlfest ( $\square)$

Department of Neurosurgery, University of Minnesota

Medical School, 2001 6th St. SE, 3500B LRB/MTRF,

Minneapolis, MN 55455, USA

e-mail: Ohlfe001@umn.edu

W. Chen

Department of Pediatrics, University of Minnesota Medical

School, Minneapolis, MN 55455, USA

W. C. Low - J. R. Ohlfest

Cancer Center, University of Minnesota Medical School,

Minneapolis, MN 55455, USA

W. C. Low · J. R. Ohlfest

Stem Cell Institute, University of Minnesota Medical

School, Minneapolis, MN 55455, USA

A. $\mathrm{Wu}$

Department of Neurosurgery, First hospital of China

Medical University, Liaoning 110001, P.R. China 